\title{
CITATION
}

\section{Medium, Small and Medium Enterprises and Digital Platforms}

New business platforms are a must for companies that disrupt new media technology, especially in the era of Covid 19. However, many incumbent companies are less able to keep up with changing business trends. Anticipating all changes in the competitive climate in the digital era in carrying out corporate transformation programs in line with the implementation of good corporate governance values to avoid greater danger and risk of failure. The qualitative method used in this research is a case study approach. Analysis on efforts to raise Medium, Small, and Medium Enterprises (MSMEs) that contribute to improving the Indonesian economy. The findings show that credit, training.

Upper-middle groups whose incomes are not compromised choose to save rather than remember, considering they don't know when the Covid-19 pandemic will end and when the situation will return to normal. The Covid-19 pandemic has increased people's income and purchasing power. People's savings are decreasing to reduce consumption consumption, especially for those who have been laid off or laid off, resulting in depleting household sources of funds. The public's uncertainty in consuming is likely to continue and consumers tend to wait and see because they have to regulate competition with tight low incomes. Small and medium enterprises are increasingly squeezed by this situation. People tend to only spend on basic necessities, while unplanned purchases are getting lower.

Social protection programs, such as social assistance, are demand-side interventions in preventing a decline in people's purchasing power with the aim of selecting the purchasing power of the poor and vulnerable. The economic recovery program is aimed more at MSMEs, which contribute $99 \%$ to the national economy. Entrepreneurs are in dire need of liquidity assistance programs ranging from restructuring, relaxation, and new capital assistance. Various economic recovery programs have been launched by the government, such as presidential assistance for micro-enterprises, the provision of salary subsidies for formal workers through the Employment Social Security Administration (BPJS Ketenagakerjaan), the MSME website, and the launch of the MSME Digital Market for the purchase of domestic MSME products. All government programs for economic recovery must be carried out in a transparent and accountable manner.

The rapid penetration of the internet in Indonesia raises hopes for information technology that can empower individuals who have been far from the center of the economy and politics. More than $50 \%$ of Indonesia's population is currently connected to the internet, and various aspects of people's lives are increasingly connected in the digital space for business, social interaction, finance, health care, and education. The use of digital financial services has the opportunity to encourage the internet economy and is expected to support the financing of the productive sector. However, the biggest problem in financing the productive sector is the low productivity of ultra-micro scale businesses. A mature strategy and policy is needed to make the internet an increase in the competitiveness of Indonesian MSMEs at the national and global levels.

With a contribution of $61.1 \%$ to Gross Domestic Product, the recovery of the ultra-micro and MSME sectors is very urgent amid the pressures of the Covid-19 pandemic. However, the facts show that the problems faced by business actors are so complex that stimulus assistance and capital alone are deemed inadequate. It turns out that micro, small and medium entrepreneurs really need assistance, such as entering the digital system economy, opening new markets, and increasing product 
competitiveness. Likewise, communication and socialization are needed in efforts to empower MSMEs, including solutions to raw material problems and increasing MSME certainty consistently. The recovery of MSMEs cannot be separated from the use of information technology, considering that digitalization is the key for business actors to be able to survive and thrive in the midst of the Covid-19 pandemic. Because of their strategic role in development, MSMEs must continue to be developed. There must be reciprocal strengthening between MSMEs and large businesses in the context of equity and realizing the greatest possible welfare for the whole community. The government is obliged to direct, guide, protect, and foster the business climate.

The development of MSMEs in the district/city/provincial development dimension based on a people's economic system is aimed not only at reducing the problem of inequality between groups, income, between actors, and employment, but also to expand the economy. business world and make a significant contribution in accelerating structural changes, namely by increasing the national economy and national economic resilience. Efforts to strengthen and empower MSMEs have been carried out by the Central/Provincial/Regency/City Governments, State/Regional Owned Enterprises, non-profit organizations and several large-scale private companies/national/foreign joint ventures.

In an effort to expand the market, both domestically and abroad, MSMEs need halal certification in order to be able to penetrate member countries of the Organization of Islamic Cooperation (OIC) in food, cosmetic and medicinal products. It should be noted that the market share of these three products is still below Brazil, France, Germany and the United States. In addition, the government is also trying to make halal certificates issued by Indonesia acceptable in all export destination countries and able to penetrate the export market without being constrained by tariff and non-tariff barriers. are required to be able to personalize their digital tools and open up to the community they need. According to Phil Simon (2011), the actual platform is not something new in the business world. Users of Customer Technology have also taken advantage of services with platforms to reach and connect with each other in transactions, both goods and services. The business platforms that are currently developing are no longer based on physical assets and natural resources, but are assisted by collaborative function technology, such as Bukalapak, Blibli, Tokopedia, Shopee, Traveloka, and Lazada, including financial technology start-ups.

\section{Bibliography}

Tayibnapis, A. Z., Wuryaningsih, L. E., \& Gora, R. (2021). Medium, Small and Medium Enterprises and Digital Platforms . South Asian Journal Of Social Studies and Economics. 